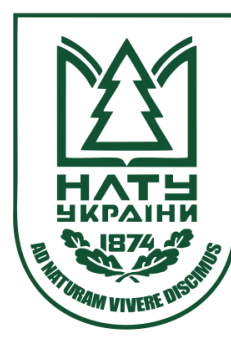

Науковий вісник НлтУ України Scientific Bulletin of UNFU

ISSN 1994-7836 (print)

https://nv.nltu.edu.ua

https://doi.org/10.15421/40280707

T. F. Chipilyak

Article received 15.08.2018 p.

Article accepted 26.09.2018 p.

chipiljak@i.ua

удк 582.675.1+581.522.4 (477.63)

О. М. Лещенюк, О. О. Лінкевич, Т. Ф. Чипиляк

Криворізький ботанічний сад, НАН Украӥни, м. Кривий Ріг, Украйна

\title{
ПЕРСПЕКТИВИ ВИКОРИСТАННЯ СОРТУ ПІВОНІЇ ТРАВ'ЯНИСТОЇ ДЛЯ ОЗЕЛЕНЕННЯ В УМОВАХ ПРАВОБЕРЕЖНОГО СТЕПОВОГО ПРИДНІПРОВ'Я
}

\begin{abstract}
Наведено результати комплексного вивчення 50 сортів Paеonia $\times$ hybryda hort. колекційного фонду Криворізького ботанічного саду НАН України, які пройшли інтродукційне випробування протягом 1982-2017рр. Район інтродукції (Криворіжжя) розташований у степовій природній зоні й належить до посушливих районів України. За висотою колекційні сорти поділено на низькорослі (висота 50-60 см), середньорослі (70-80 см) і високорослі (понад 90 см); за формою квітки - немахрові, махрові, анемоновидні; за величиною квітки - дрібноквіткові, середньоквіткові, великоквіткові та 3 найбільшим понад 19 см діаметром. Найбільшу кількість квітконосів формував густомахровий сорт 'Amabilis superbissima' - 18-36 шт. Узагальнено особливості сезонного ритму розвитку півонії трав'яної і з'ясовано, що відростали колекційні зразки в I-II декаді квітня, квітували з II декади травня по I декаду червня протягом 26-31 діб. Завершували вегетацію сорти в кінці листопада, а тривалість вегетації становила 224-235 діб. Внаслідок сортовивчення виділено 12 перспективних, адаптованих до умов Правобережного степового Придніпров'я сортів півонії трав'янистої. Установлено, що в умовах Криворіжжя вони проходять повний цикл фенологічного розвитку, характеризуються тривалим та пишним квітуванням, не пошкоджуються хворобами та шкідниками, що відповідає вимогам декоративного садівництва.
\end{abstract}

Ключові слова: Paeonia $\times$ hybryda hort.; інтродукція; сортовивчення; Криворіжжя.

Вступ. Декоративне садівництво є складовою частиною ландшафтного будівництва, яке забезпечує стійкість та екологічну ефективність зелених насаджень в урбогенному середовищі та відіграє важливу роль у розвитку сучасного міста (Zaimenko et al., 2015). Трав'яниста півонія, як декоративна культура, відома людству ще $з$ давніх-давен і дотепер має велику популярність. Надзвичайна краса різнобарвних квіток півонії та їх форми, розсічені листки, компактність кущів, пишне цвітіння, декоративність впродовж всієї вегетації, невибагливість до умов зростання, можливість тривалий період рости на одному місці без пересадки, стійкість до пошкодження хворобами та шкідниками, здатність цвісти в напівзатінених місцях, вишуканий аромат від трояндового до різноманітних пряних, сприяють частому застосуванню цієї культури в озелененні. Півонія має значну екологічну пластичність, що підтверджується іiі культивуванням у багатьох інтродукційних центрах із різноманітними природно-кліматичними умовами (Catalog, 1997; Gayshun, 2006; Reut \& Myronova, 2013; Yefimov, 2014; Gorobets, 2015).

Проте в ландшафтному дизайні квітникових композицій Кривого Рогу (використовується лише 2 сорти) їх часто не застосовують (Chypylyak et al., 2014). Однією 3 причин недостатнього використання півонії в озеленені міст Криворіжжя $\epsilon$ відсутність інформації про їхні еколого-біологічні особливості та декоративні властивості

в наших умовах, технології вирощування та способи їх використання. Натомість, інтродукція півонії трав'янистої з 1982 р. у Криворізькому ботанічному саду НАН України (КБС) сприяе як збереженню її біорізноманіття, так і залученню величезного асортименту в культуру. Перший садівний матеріал живців для колекції отримали з ЦБС НАН України ім. Гришка, м. Київ та Донецького ботанічного саду НАН України (ДБС), м. Донецьк (30 сортів). Наступні поповнення колекційного фонду півонії Paeonia $\times$ hybryda hort. відбулися з цих же Садів та ботанічного саду Дніпропетровського державного університету, м. Дніпро у 1994-1998 pp. (20 сортів), у 2008-2009 pp. (18), у 2014-2016 pp. (34 сорти). Провідна роль у створенні та збагаченні колекційного фонду сортів Paeonia $\times$ hybryda hort. КБС належить двом ботанічним садам - ЦБС ім. Гришка (59 сортів) та ДБС (42 сорти). Наразі нашу колекцію представлено 83 сортами різних садових груп вітчизняної та зарубіжної селекції.

Мета роботи - провести комплексний аналіз колекційного фонду півонії трав'янистої для визначення високодекоративних сортів, перспективних для культивування в умовах Правобережного степового Придніпров'я.

Матеріали та методи дослідження. Дослідження проводили на базі Криворізького ботанічного саду НАН України. Матеріалом дослідження бути рослини

Інформація про авторів:

Лещенюк Олена Миколаївна, пров. інженер, відділ природної та культурної флори. Email: fedorova8@bigmir.net

Лінкевич Олена Олександрівна, пров. інженер, відділ природної та культурної флори. Email: alonalinkevic@gmail.com Чипиляк Тетяна Федорівна, канд. біол. наук, в.о. завідувача відділу природної та культурної флори. Email: chipiljak@i.ua Цитування за ДСту: Лещенюк О. М., Лінкевич О. О., Чипиляк Т. Ф. Перспективи використання сорту півонії трав'янистої для озеленення в умовах правобережного степового Придніпров'я. Науковий вісник НЛтУ України. 2018, т. 28, № 7. С. 36-39.

Citation APA: Leshcheniuk, E. M., Linckevych, O. O., \& Chipilyak, T. F. (2018). Promising varieties of grass peony for use in landscaping in the conditions of right-bank steppe Dnieper. Scientific Bulletin of UNFU, 28(7), 36-39. https://doi.org/10.15421/40280707 
50 сортів Paeonia $\times$ hybryda hort. колекції КБС. Фенологічні спостереження у 2010-2017 рр. проводили за загальноприйнятою методикою (Metodika, 1975). Життєву форму виділено за класифікацією Х. Раункієра (Raunkiaer, 1907) та I. Г. Серебрякова (Serebryakov, 1964), феноритмотип - за I. В. Борисовою (Borisova, 1972). Декоративні характеристики колекційних сортів визначали за Н. М. Дудик та В. Ф. Горобцем (Dudyk \& Kharchenko, 1987; Gorobets, 2015).

Район інтродукції (Криворіжжя) розташований на південному заході Дніпропетровської обл., у степовій природній зоні. Він належить до посушливих районів України, кількість атмосферних опадів становить 425450 мм/рік (з максимумом на початку літа) (Kazakov et al., 2005). У теплий період спостерігаємо суховії за дуже низької відносної вологості повітря - 25-30 \%. Літо відзначається тривалими посухами за наявності високої аномальної температури $\left(36,7-38,1^{\circ} \mathrm{C}\right)$ та незначної кількості опадів або їх відсутності. Зимовий період характеризується складними кліматичними умовами, коли звичайним явищем $є$ ожеледь, застій води на поверхні грунту, часті відлиги (кількість таких днів - 45) після яких зазвичай, бувають короткочасні, але великі від'ємні температури $\left(-27^{\circ} \mathrm{C}--30^{\circ} \mathrm{C}\right)$.

Результати дослідження та їх обговорення. У наших умовах представники сортів Paeonia $\times$ hybryda hort. за життєвою формою - трав'янисті полікарпіки, геофіти, за екоморфою - геліофіти, але легко проявляються як геліосциофіти, за гідроморфою - мезофіти, за феноритмотипом належать до групи весняно-літньо-осінньозелених рослин.

Декоративність рослин у нових умовах залежить від їхньої здатності відтворювати притаманні їм сортові о3наки, що проявляється у зовнішньому стані рослин та в характері проходження основних фенофаз. Для виявлення відповідності параметрів рослин їх сортовим характеристикам в умовах КБС досліджено біометричні показники (висота генеративного пагона та їх кількість, форма та діаметр квітки, кількість квіток на квітконосі) 50 сортів півонії трав'янистої, що дало змогу визначити рівень декоративності сорту та квіткову продуктивність. Основні морфометричні параметри рослин залежали від багатьох чинників: погодно-кліматичних умов року, сортових особливостей рослин, періоду вегетації. За висотою колекційні сорти поділено на 3 групи: низькорослі (висота 50-60 см) презентовані 6 сортами - 'Rubens', 'Beregynia', 'Kozachok' та ін., високорослі (понад 90 см) об'єднують 12 сортів - 'M-me Renee Dessert', 'Rosea Elegans', 'Mons. Jules Elie' та ін. і середньорослі (7080 см), які представлені найбільшою кількістю сортів (32) - 'Chervonyi Oksamyt', 'Edulis Superba', 'Felix Crousse', 'Lyubimets Parkov' та ін.

За формою квітки особини досліджуваних сортів півонії належать до 4 садових груп: немахрові - 'The Bride', 'M-me Marine'; напівмахрові - 'Eduard Andre', 'M-me Renee Dessert', 'Albatre' та ін.; анемоновидні'Zhemchuzhnaya Rossyp', 'Big Ben' та ін. і махрові (становлять 60 \% колекції) - 'Beregynia', 'Sarah Bernhardt', 'M-me Modest', 'Amabilis superbissima', 'Rubens', 'Mons. Jules Elie'. За величиною квітки сорти розподілено: дрібноквіткові (діаметр квітки менше 12 см) - 9 сортів ('Kozachok', 'Marie Lemoine', 'Nigricans' та ін.), середньоквіткові (12-15 см), які становлять 49 \% колекції ('Lebed', 'Primevere' та ін.), великоквіткові (15-19 см)-
16 сортів ('Eduard Andre', 'Edulis superba', 'Rubens' та ін.) i найменшою кількістю представлено групу рослин із найбільшим діаметром квітки (20-22 см)- 3 сорти ('President Taft', 'Mons. Jules Elie' та 'Pamyat' o Paustovskom'). Хоч дотепер перевагу надають сортам із великими квітками, потрібно враховувати міцність квітконосів, на яких вони сформовані, оскільки у деяких сортів ('Primevere', 'Sarah Bernhardt' та ін.) стебла в дощову погоду полягають, знижуючи декоративність рослин. Ми виявили, що з 50 колекційних сортів завдяки міцності генеративного пагона форму кущів зберігають махрові сорти: 'President Taft', 'Rubens', 'Beregynia', 'Lord Kitchener, 'M-me Marine', 'Felix Supreme'.

Позаяк від кількості генеративних пагонів та кількості утворених квіток на них залежить тривалість та інтенсивність квітування, ми провели аналіз генеративної продуктивності сортів. Дослідження показали, що найбільше генеративних пагонів серед групи немахрових сортів утворювали культивари сорту 'Bride' - 710 квітконосів. Сорти напівмахрової групи - 'Madame Renee Dessert', 'Albatre', 'Eduard Andre' та ін. - формували однакову кількість квітконосів - 14-19. Серед махрових значну кількість квітконосних пагонів утворюють сорти: 'Amabilis superbissima' - 16-20, 'M-me Modest' - 12-14, 'Pamyat' o Paustovskom' - 10-13, натомість найменшу - 4-8 - 'Modeste Guerin'. Серед густомахрових сортів найбільшу кількість генеративних пагонів за вегетаційний період формують 'Amabilis superbissima' 18-36, 'M-me Renee Dessert' - 18-31, 'Mon. Julles Elie' 18-24, 'Belyy Lebed' - 10-13.

Утворення найбільшої кількості квіток на одному генеративному пагоні властиве особинам сорту 'Rosea Elegans' - 7-10 шт. та 'Mons Jules Elie' - 4-6 шт., до того ж цей сорт має і великий діаметр квітки - до 18 см, що підкреслює його високі декоративні властивості. На зразках інших сортів за період квітування на одному квітконосі утворюється по 2-4 квітки. В окремі роки на рослинах деяких сортів зафіксовано зменшення кількості генеративних пагонів та їх висоти, кількості квіток на квітконосі, їх діаметра, що пояснюємо несприятливими метеорологічними умовами осені (тривала посуха) попереднього вегетаційного періоду, коли відбувається формування генеративних бруньок.

Фенологічні дослідження дають змогу визначити терміни настання та проходження основних фаз розвитку, тривалості цвітіння, оптимальні терміни висадки рослин півонії, що важливо для використання їх у ландшафтному дизайні. За результатами довгострокових інтродукційних досліджень фенологічних фаз розвитку встановлено, що в наших кліматичних умовах відростання колекційних сортів відбувалося в I-II декаді квітня, цвітіння - 3 II декади травня по I декаду червня протягом 26-31 $\left(28,5^{ \pm 2,5}\right)$ діб. Найтривалішим періодом квітування - 14-17 $\left(15,5^{ \pm 1,5}\right)$ діб - відзначилися сорти 'Rosea Elegans', 'President Taft', 'Edulis Superba', 'Modest Guerin', 'Beregynia', 'Albatre'. Завершували вегетацію досліджувані сорти у II - III декаді листопада. Тривалість вегетації колекційних зразків становила 224-235 $\left(229,5^{ \pm 5,5}\right)$ діб.

Для озеленення та ландшафтного дизайну оцінюють види та сорти півонії насамперед за декоративними ознаками. Сорти повинні відповідати таким вимогам: мати різноманітне забарвлення, діаметр та форму квітки; компактний щільний кущ із красивою формою листової 
пластинки; пишне квітування 3 подовженим періодом; бути стійкими до полягання хвороб та шкідників. За означеними вище критеріями проведено комплексний аналіз сортів різних садових груп, які в умовах Саду пройшли інтродукційне випробування понад 10 років. Отже, ми виділили групу найперспективніших для використання в озелененні сортів Paeonia $\times$ hybryda hort. колекції КБС НАН України (таблиця).

Таблиця. Сорти Paeonia ×hybryda hort., перспективні для декоративного садівництва Криворіжжя

\begin{tabular}{|c|c|c|c|c|c|c|c|c|}
\hline Назва сорту & Група & $\begin{array}{c}\text { Висота } \\
\text { куща, см }\end{array}$ & $\begin{array}{c}\text { Ширина } \\
\text { куща, см }\end{array}$ & $\begin{array}{c}\text { Кількість квіт- } \\
\text { коносів, шт. }\end{array}$ & $\begin{array}{c}\text { Діаметр } \\
\text { квітки, см }\end{array}$ & $\begin{array}{c}\text { Початок } \\
\text { вегетації }\end{array}$ & $\begin{array}{c}\text { Початок } \\
\text { цвітіння }\end{array}$ & $\begin{array}{c}\text { Тривалість } \\
\text { цвітіння, діб }\end{array}$ \\
\hline 'Albatre' & $\begin{array}{c}\text { Напівмахровий, } \\
\text { кремовий }\end{array}$ & $80^{ \pm 10}$ & $100^{ \pm 10}$ & $19^{ \pm 4}$ & $10-14$ & $8.04^{ \pm 7}$ & $23.05^{ \pm 3}$ & $14,0^{ \pm 2}$ \\
\hline 'Beregynia' & $\begin{array}{c}\text { Махровий, } \\
\text { насиченорожевий }\end{array}$ & $55^{ \pm 5}$ & $65^{ \pm 2}$ & $9^{ \pm 3}$ & $12-14$ & $13.04^{ \pm 2}$ & $20.05^{ \pm 6}$ & $13,0^{ \pm 2}$ \\
\hline 'Big Ben' & $\begin{array}{c}\text { Махровий, } \\
\text { насиченочервоний }\end{array}$ & $80^{ \pm 10}$ & $50^{ \pm 10}$ & $8^{ \pm 2}$ & $12-15$ & $8.04^{ \pm 7}$ & $27.05^{ \pm 5}$ & $14,0^{ \pm 3}$ \\
\hline $\begin{array}{c}\text { 'Edulis Super- } \\
\text { ba' }\end{array}$ & $\begin{array}{c}\text { Махровий, } \\
\text { насиченорожевий }\end{array}$ & $75^{ \pm 4}$ & $105^{ \pm 10}$ & $11^{ \pm 5}$ & $16-18$ & $8.04^{ \pm 7}$ & $21.05^{ \pm 5}$ & $14,5^{ \pm 5}$ \\
\hline $\begin{array}{c}\text { 'Felix Supre- } \\
\text { me' }\end{array}$ & $\begin{array}{c}\text { Густо-махровий, } \\
\text { червоно-малиновий }\end{array}$ & $70^{ \pm 10}$ & $80^{ \pm 10}$ & $14^{ \pm 3}$ & $13-15$ & $8.04^{ \pm 7}$ & $2.06^{ \pm 7}$ & $14,5^{ \pm 5}$ \\
\hline $\begin{array}{c}\text { 'Kozachok' } \\
\text { Немахровий, пурпуро- } \\
\text { во-червоний }\end{array}$ & $60^{ \pm 5}$ & $65^{ \pm 5}$ & $8^{ \pm 2}$ & $10-12$ & $8.04^{ \pm 7}$ & $15.05^{ \pm 3}$ & $13,5^{ \pm 4}$ \\
\hline $\begin{array}{c}\text { 'Lord Kitche- } \\
\text { ner' }\end{array}$ & $\begin{array}{c}\text { Густомахровий, } \\
\text { вишнево-червоний }\end{array}$ & $80^{ \pm 10}$ & $95^{ \pm 10}$ & $12^{ \pm 4}$ & $11-15$ & $8.04^{ \pm 7}$ & $21.05^{ \pm 5}$ & $13,5^{ \pm 3}$ \\
\hline $\begin{array}{c}\text { 'Lyubimets } \\
\text { Рarkov' }\end{array}$ & $\begin{array}{c}\text { Напівмахровий, } \\
\text { світло-рожевий }\end{array}$ & $85^{ \pm 10}$ & $90^{ \pm 10}$ & $11^{ \pm 4}$ & $13-15$ & $8.04^{ \pm 7}$ & $27.05^{ \pm 5}$ & $14,0^{ \pm 2}$ \\
\hline $\begin{array}{c}\text { 'President Таft' } \\
\text { міжно-ровий, } \\
\text { 'Rosea Ele- } \\
\text { gans' }\end{array}$ & $\begin{array}{c}\text { Махровий, } \\
\text { рожево-бузковий }\end{array}$ & $80^{ \pm 2}$ & $85^{ \pm 2}$ & $8^{ \pm 2}$ & $10-12$ & $8.04^{ \pm 7}$ & $21.05^{ \pm 6}$ & $15,5^{ \pm 2}$ \\
\hline 'Rubens' & $\begin{array}{c}\text { Густомахровий, } \\
\text { рожевий }\end{array}$ & $60^{ \pm 10}$ & $105^{ \pm 4}$ & $15^{ \pm 3}$ & $16-18$ & $7.04^{ \pm 6}$ & $21.05^{ \pm 5}$ & $13,0^{ \pm 2}$ \\
\hline $\begin{array}{c}\text { 'Zhemchuzhna } \\
\text { уа Rossyp' }\end{array}$ & $\begin{array}{c}\text { Анемоновидний, } \\
\text { сріблясто-рожевий }\end{array}$ & $70^{ \pm 10}$ & $90^{ \pm 10}$ & $12^{ \pm 3}$ & $15-17$ & $10.04^{ \pm 3}$ & $23.05^{ \pm 4}$ & $14,0^{ \pm 2}$ \\
\hline
\end{tabular}

Представники цієї групи мають високі декоративні показники: зберігають або перевищують габітус, притаманний сорту, пишно цвітуть близько 14 діб, не пошкоджуються весняними суховіями та літньою спекою, а взимку - морозами та відлигами, стійкі до пошкодження хворобами i шкідниками. Основні показники життєвого стану рослин свідчать про успішність їх культивування в умовах Правобережного степового Придніпров'я, що робить їх цінним потенційним матеріалом для використання у декоративному садівництві нашого регіону. За участі сортів Paeonia $\times$ hybryda hort. 3 різними термінами та тривалістю цвітіння в поєднанні 3 іншими квітниково-декоративними видами, можна створити ефект безперервності квітування, забезпечити динамізм та багатоаспектність квітникових композицій промислових міст.

Для популяризації півонії трав'янистої на Криворіжжі у Криворізькому ботанічному саду у 2015 р. створено експозицію "Сад півонії" за участі сортів колекційного фонду квітково-декоративних рослин, яка наповнила красою та ароматом весняний простір серед існуючих ландшафтних композицій КБС. На новоствореній експозиції "Сад півонії" та на колекційній ділянці співробітники Саду проводять пізнавальні екскурсії. Серед відвідувачів, школярів, студентів та гостей м. Кривий Ріг ведуть роз'яснювальну роботу щодо еколого-біологічних особливостей росту та розвитку півонії, способів розмноження, догляду за цією культурою в наших умовах.

Висновки. Внаслідок сортовивчення 50 сортів Paeonia $\times$ hybryda hort. зарубіжної та вітчизняної селекції виділено 12 перспективних, адаптованих до умов Правобережного степового Придніпров'я, сортів, які мають високі декоративні властивості. Встановлено, що в умовах Правобережного степового Придніпров'я вони проходять повний цикл фенологічного розвитку, який узгоджується 3 погодно-кліматичними умовами нашого регіону. При цьому зберігають всі біоморфологічні показники, притаманні цим сортам, характеризуються тривалим та пишним квітуванням, мають компактний кущ, не пошкоджуються хворобами та шкідниками, що відповідає вимогам декоративного садівництва.

\section{Перелік використаних джерел}

Borisova, I. V. (1972). Sezonnaya dinamika rastitelnogo soobshchestva. [Seasonal dynamics of the plant community]. Polevaya geobotanika. [Field geobotany], 4, 5-11. [In Russian].

Catalog. (1997). Katalog tsvetochno-dekorativnykh travyanistykh rasteniy botanicheskikh sadov SNG i stran Baltii / Sovet botanich. sadov Rossii. Tsentr. botanich. Sad AN Belarusi. [Catalog of floralornamental herbaceous plants of the botanical gardens of the CIS and the Baltic States / Botanical Council. Gardens of Russia. Centre. Botanic. Garden of the Academy of Sciences of Belarus]. Minsk: Izd. E. S. Halperin, 476 p. [In Russian].

Chypylyak, T. F., Mazura, M. Yu., Bereslavska, O. O., \& Leshchenyuk, O. M. (2014). Kvitnykovo-dekoratyvne oformlennya parkiv ta skveriv m. Kryvyy Rih. Stan, problemy, rekomendatsiyi shchodo yoho polipshennya. [Flower Design of Parks and Squares in the city of Krivoy Rog: Condition, Problems and Recommendations for improvement]. Scientific Bulletin of UNFU, 24(4), 164-169. [In Ukrainian].

Dudyk, N. M., \& Kharchenko, E. D. (1987). Pyony. Kataloh-spravochnyk. [Peonies. Catalog-directory]. Kyiv: Naukova dumka, 127 p. [In Russian].

Gayshun, V. V. (2006). Piony: rekomendatsii po vyrashchivaniyu $i$ ukhodu. [Peonies: recommendations for growing and care]. Minsk, 32 p. [In Russian].

Gorobets, V. F. (2015). Piony (biologiya, selektsiya, sorta). [Peonies (biology, breeding, varieties)]. Kyiv: Veles, 160 p. [In Russian].

Kazakov, V. L., Paranko, I. S., \& Smetana M. H. (2005). Pryrodnycha heohrafiya Kryvbasu. [Natural geography of Kryvbas]. Krivoy Rog: KDPU, 156 p. [In Ukrainian].

Metodika. (1975). Metodika fenologicheskikh nablyudeniy $v$ botanicheskikh sadakh SSSR. [The methodology of phenological observations in the botanical gardens of the USSR]. Moscow: GBS AN SSSR, 27 p. [In Russian]. 
Raunkiaer, C. (1907). Planterigets Livsformes of deres Betydning for Geografies. Kobenhavn: Nordiskforlag, 132 r.

Reut, A. A., \& Myronova, L. N. (2013). Mnohoobrazye pyonov dlya ozelenenyya horodskykh terrytoryy. [Variety of pions for gardening of urban territories]. Rol botanichnykh sadiv $i$ dendroparkiv $u$ zberezhenni ta zbahachenni biolohichnoho riznomanittya urbanizovanykh terytoriy: Materialy mizhnar. nauk. konf. (pp. 139-141). Kyiv: NTSEBM NAN Ukrayiny, PAT "Vipol". [In Russian].

Serebryakov, I. G. (1964). Zhiznennyye formy vysshikh rasteniy i ikh izucheniye. [Life forms of higher plants and their study]. Polevaya botanika. [Field botany], 3, 146-208. [In Russian].

Yefimov, S. V. (2014). Kompleksnoye izucheniye i otsenka morfologicheskikh priznakov piona (Paeonia L.) pri introduktsii. [Complex study and evaluation of the morphological features of the pion (Paeonia L.) during introduction]. (Vol. 27). Uchenyye zapiski Tavricheskogo universiteta im. V. I. Vernadskogo. Seriya Biologiya, Khimiya, 5(66), 47-62. [In Russian].

Zaimenko, N. V., Cherevchenko, T. M., Haponenko, M. B., \& Rakhmetov, D. B. (2015). Zberezhennya ta zbahachennya bioriznomanittya roslyn u Natsionalnomu botanichnomu sadu im. M. M. Hryshka NAN Ukrayiny. [Preservation and enrichment of plant biodiversity in the National Botanical Garden named after. M. M. Grisha of the National Academy of Sciences of Ukraine]. Introduktsiya roslyn, zberezhennya ta zbahachennya bioriznomanittya $v$ botanichnykh sadakh ta dendroparkakh: Materialy naukovoyi konferentsiyi. (pp. 14-17). Kyiv: Fitosotsiotsentr. [In Ukrainian].

Е. Н. Лещенюк, Е. А. Линкевич, Т. Ф. Чипиляк

Криворожский ботанический сад, НАН Украины, г. Кривой Рог, Украина

\title{
ПЕРСПЕКТИВЫ ИСПОЛЬЗОВАНИЯ СОРТА ТРАВЯНИСТОГО ПИОНА ДЛЯ ОЗЕЛЕНЕНИЯ В УСЛОВИЯХ ПРАВОБЕРЕЖНОГО СТЕПНОГО ПРИДНЕПРОВЬЯ
}

\begin{abstract}
Приведены результаты комплексного изучения 50 сортов Paеonia $\times$ hybryda hort. коллекционного фонда Криворожского ботанического сада НАН Украины, которые прошли интродукционное испытание в течение 1982-2017 гг. Район интродукции (Криворожье) расположен в степной природной зоне и относится к засушливым районам Украины. По высоте коллекционные сорта разделены на низкорослые (высота 50-60 см), среднерослые (70-80 см) и высокорослые (более 90 см); по форме цветка - немахровые, махровые, анемоновидные; по величине цветка - мелкоцветковые, среднецветковые, крупноцветковые и с наибольшим более $19 \mathrm{~cm}$ диаметром. Наибольшее количество цветоносов формировал густомахровый сорт 'Amabilis superbissima' - 18-36 шт. Обобщены особенности сезонного ритма развития пиона травянистого и выяснено, что отрастали образцы в I-II декаде апреля, цвели - co II декады мая - I декады июня в течение 26-31 дней. Заканчивали вегетацию сорта в конце ноября, а продолжительность вегетации составила 224-235 дня. В результате сортоизучения выделено 12 перспективных, адаптированных в условиях Правобережного степного Приднепровья сортов пиона травянистого. Выяснено, что в условиях Криворожья они проходят полный цикл фенологического развития, характеризуются длительным и пышным цветением, не поражаются болезнями и вредителями, что соответствует требованиям декоративного садоводства.
\end{abstract}

Ключевые слова: Paeonia $\times$ hybryda hort.; интродукция; сортоизучение; Криворожье.

E. M. Leshcheniuk, O. O. Linckevych, T. F. Chipilyak Kryvyi Rih Botanical Garden, NAS Ukraine, Kryvyi Rih, Ukraine

\section{PROMISING VARIETIES OF GRASS PEONY FOR USE IN LANDSCAPING IN THE CONDITIONS OF RIGHT-BANK STEPPE DNIEPER}

Herbaceous peony in the landscape design of flower arrangements of Kryviy Rih is represented by only two varieties because of the lack of information about its ecological and biological features and decorative character in our conditions. The purpose of the research of the collection fund Paeonia $\times$ hybryda hort. of Kryvyi Rih Botanical Garden of the National Academy of Sciences of Ukraine (hereinafter KRBG) is to determine the high-decorative, promising for cultivation in the conditions of Right-bank Steppe Dnieper, varieties. The materials of the study were the plants of 50 varieties Paeonia $\times$ hybryda Hort. collection of KRBG. Phenological observations in 2010-2017 were conducted according to the generally accepted methodology (Methodology, 1975). The decorative characteristics Paeonia $\times$ hybryda Hort. were determined by Dudyk and Horobets (Dudyk \& Kharchenko, 1987; Horobets, 2015). The introduction area (Krivorozhya) is located in the southwest of the Dnipropetrovsk Region, in the steppe natural zone. Morphometric indices such as height of the generative shoots and their number, shape and diameter of the flower, number of flowers on the peduncle, and habitus of bushes of 50 varieties of herbaceous peony have been investigated to determine the level of decorative varieties. We found that they depended on weather-climatic conditions of the year, varietal characteristics and vegetation period. We have summarized the results of the study of seasonal rhythm of varieties development in the conditions of Kryvorizhya. It is established that in our climatic conditions, the regrowth of the varieties occurred in the I-II decade of April, the flowering phase in the II decade of May - I decade of June and lasted until the middle of July 26-31 $\left(28.5^{ \pm 2.5}\right)$ days. The vegetation of these sorts was ended in the IIIII decade of November. There are 12 prospective varieties for mass planting. It was found that in the conditions of the Right-bank Steppe Dnieper, they undergo a complete cycle of phenological development, which is agreed with weather and climatic conditions. At the same time, all the biomorphological indices inherent in these varieties are retained. They are characterized by long and lush flowering, availability of a compact bush, resistance by diseases and pests that replies requirements of ornamental horticulture.

Keywords: Paeonia $\times$ hybryda Hort.; introduction; variety study; seasonal rhythm of development; Krivyi Rig region. 